\title{
Effects of Climate Variations on the Mechanisms of Thermoregulation in Sheep in the Southern State of Piauí, Brazil
}

\author{
Carlos Syllas Monteiro Luz ${ }^{1}$, Wéverton José Lima Fonseca ${ }^{2}$, Cícero Pereira Barros Junior ${ }^{3}$, \\ Gioto Ghiarone Terto e Sousa ${ }^{4}$, José Elivalto Guimaraes Campelo ${ }^{5}$, André Campêlo Araujo ${ }^{3}$, \\ Johnny Iglesias Mendes Araújo ${ }^{3}$, Gleissa Mayone Silva Vogado ${ }^{3}$, Tatiano Ribeiro dos Santos ${ }^{6}$ \\ \& Severino Cavalcante de Sousa Júnior ${ }^{7}$ \\ ${ }^{1}$ M.Sc of graduate in Animal Science, Federal University of Piauí, UFPI, Bom Jesus, PI, Brazil \\ ${ }^{2}$ Colleger PIBIC/CNPq, Undergraduate Course of Bachelor of Animal Science, UFPI, Brazil \\ ${ }^{3}$ Graduating in Animal Sciences, UFPI, Brazil \\ ${ }^{4}$ Multiple Higher Education Institute IESM/Timon, Maranhão, Brazil \\ ${ }^{5}$ Department of Animal Science, UFPI, Brazil \\ ${ }^{6}$ Agricultural Engineering, UFPI, Brazil \\ ${ }^{7}$ Depertamento of Human Medicine, UFPI, Brazil \\ Correspondence: Carlos Syllas Monteiro Luz, Department of Animal Science, Federal University of Piauí, Bom \\ Jesus, PI 64900-000, Brazil. Tel: 55-89-8116-4119. E-mail: syllaszoot@yahoo.com.br
}

\author{
Received: March 15, 2014 Accepted: August 7, 2014 Online Published: September 15, 2014 \\ doi:10.5539/jas.v6n10p169 URL: http://dx.doi.org/10.5539/jas.v6n10p169
}

\begin{abstract}
The sheep breeds commercially exploited in northeastern Brazil are mostly hardy, but even being considered adapted animals, they suffer physiologically to the climatic conditions of this region. The objective of this study was to evaluate the variation of physiological parameters of animals and correlate them with meteorological data on different shifts and periods of the year. The design was DBC with 10 sheep, five Santa Inês and Morada Nova five. Data were collected in the dry and rainy season every three days, being measured in animals: respiratory frequency (RF), rectal temperature (RT), heart frequency (HF) and rate of sweating (RS) and at the same time were recorded environmental variables: air temperature (AT) and humidity (HA) was calculated index Globe Temperature and Humidity (IGTH). The AT showed a range of $10.48^{\circ} \mathrm{C}$, with superiority in the dry season, the HA and the IGTH show significant difference $(\mathrm{P}<0.05)$ between periods, since the RR showed a significant difference for the shifts of the period. The HF also significantly different for the two periods and the two rounds of each period. However it was found that in the late shifts of the two periods studied sheep suffered heat stress.
\end{abstract}

Keywords: humidity, sweating, heart rate, rectal temperature

\section{Introduction}

The Northeast region is very promising for the production of small ruminants with emphasis sheep that has a flock of sheep represented by a force of approximately 9.85 million heads representing $56.7 \%$ of all national total (IBGE, 2010). Being explored mostly under extensive with little use of appropriate feeding practices, health and reproductive management system. The animals are in their most rustic, but suffer from physiological impacts that are imposed by the climatic conditions of this region. Among the breeds raised in Brazil, there is the Santa Ines native, without wool and with great variation in coat (Santos, 2003) race. Thus, the rational use of the savanna, prevalent biome in northeastern Brazil is one of the viable strategies (Costa et al., 2009).

The northeastern semiarid zone, which corresponds to $74.30 \%$ of the area of the Northeast, has a dry tropical climate, with an annual wet or rainy season from 4 to 6 months, followed by a dry season 6-8 months. The average annual rainfall is around $700 \mathrm{~mm}$ and the temperature is high throughout the year, with thermal averages between $23-28^{\circ} \mathrm{C}$ (Cezar et al., 2004). The dry season and especially the late shifts proves more stressful for the animals, it caused mainly by the increase in temperature and decrease in moisture while providing animals using physiological resources in favor of excessive heat loss imposed by the environment. Increased temperature and heat stress increases the secretion of the hormone cortisol described by Starling et al. (2005), causing a range of 
effects on metabolism that alter animal behavior and welfare (Silanikove, 2000).

Livestock in the evaluation of the adaptability of animals or animal $\mathrm{x}$ environment interaction needs attention, because this is one of the factors that influence directly in the productive results. With this in-depth study on the climatic characteristics of the region, such as its influence on physiological mechanisms of thermoregulation of animals as may have low, medium and high stress is required. The objective of this study was to evaluate some meteorological variables climate, in Bom Jesus-PI and correlate them with physiological mechanisms of thermoregulation of animals at different times of day and times of year.

\section{Materials and Methods}

The work was developed in the fold of the Technical College of Bom Jesus (CTBJ) in southern Piauí State. The municipality has coordinates: latitude $9^{\circ} 4^{\prime} 27^{\prime \prime}$ South, longitude $44^{\circ} 21^{\prime} 30^{\prime \prime}$ West and $277 \mathrm{~m}$ altitude The climate is semi-arid type which means hot and dry climate with summer rainy season, lingering for fall. High air temperature and insolation are checked throughout the year. However, there is the occurrence of a rainy season, usually starting in November and ending in early April, and a dry season from May to October.

We used a randomized block design, where the block I represented the dry period and the block II represented the rainy season, each block consisted of two treatments (morning and afternoon). 10 randomly ovine animals were chosen with an average of six months of age, five of Santa Ines and five Morada Nova breed. The sheep are raised in confinement system with two feedings daily, one in the morning shift and another in the afternoon, the facilities are roofed concrete floor of ceramic tiles and wooden feeders collective. Data were collected from 2011 to 2012 every three days during the months from August to November (dry season) the January to May (rainy season), samples were taken twice daily: morning, of 07:00 to 09:00 and the shift afternoon, from 13:00 to 15:00.

In animals were initially recorded respiratory frequency (RF), assessing respiratory movements per minute observed directly on the left flank, then recorded rectal temperature (RT), measuring by means of a clinical thermometer inserted directly into the rectum of animals during two minutes, the heart frequency (HF) measured by means of a stethoscope placed on the third rib being recorded heart beat frequency was estimated and then the rate of sweating (RS) by the calorimetric method Schleger and Turner (1965) adapted by Silva (2000).

To estimate the TS was used filter paper $\mathrm{n}^{\circ} 01$ bored with the aid of a manual paper punch having $0.5 \mathrm{~cm}$ diameter disc, and soon after immersed in aqueous solution of $10 \%$ cobalt chloride, and then dried in an oven at $105^{\circ} \mathrm{C}$ for $6 \mathrm{~h}$, when dried showed intense blue violet color. Three of these discs were mounted on microscope slides and fixed therein with type "durex" transparent tape. These slides were stored in a desiccator for protection against humidity, while it gains moisture shall be a light pink color. Slides were prepared in maximum 12 hours in advance of use. With the aid of a scalpel blade was made in the shaved dorsal part of the animal on the right side of each animal. After cleaning the grease and grime was performed with alcohol and paper towel after cleaning tape with the three discs was applied and started counting the time so that they can know the time of each turn, each controlled separately disk turning on each time in seconds.

The environment were recorded: The air temperature (AT) and humidity (HA) that were collected in the weather are the Campus Professor Cinobelina Elvas, next to the fold where animals are exploited temperatures were recorded black globe thermometer moisture was measured using a globe with approximately $15 \mathrm{~cm}$ in radius, with dark painted with a thermometer $30 \mathrm{~cm}$ in ink, which was collected temperature 20 minutes after the beginning and end of each shift the collection, which was estimated to the temperature of the rumen of the animals. However, the value of the black globe temperature for the index calculation is required which is obtained from a dry bulb thermometer in the center of a hollow sphere of copper, with a diameter of $15 \mathrm{~cm}$ and a thickness of $0.5 \mathrm{~mm}$, externally painted with matt black paint (Ferreira, 2005).

According to the physical environment analysis, we calculated the index Globe Temperature and Humidity (IGTH), according to the methodology used by Sousa Jr et al. (2008), using the equations below:

Partial Vapor Pressure $(\mathrm{Pp}\{\mathrm{ta}\})$ :

$\mathrm{Pp}\{\mathrm{Ta}\}=\mathrm{Ps}\{\mathrm{Tu}\}-\gamma(\mathrm{Ta}-\mathrm{Tu})$

Being Ps $\{\mathrm{Tu}\}=$ saturation pressure at temperature $\mathrm{Tu}(\mathrm{kPa}) ; \gamma=$ psychrometric constant $\left(\mathrm{kPa} /{ }^{\circ} \mathrm{C}\right) ; \mathrm{Ta}=$ air or dry bulb $\left({ }^{\circ} \mathrm{C}\right) ; \mathrm{Tu}=$ wet bulb $\left({ }^{\circ} \mathrm{C}\right)$.

Index Globe Temperature and Humidity (IGTH):

$\mathrm{IGTH}=\mathrm{Tg}+0.36 \mathrm{Tpo}+41.5$

With $\mathrm{Tg}=$ globe thermometer temperature $\left({ }^{\circ} \mathrm{C}\right)$; $\mathrm{Tpo}=\operatorname{dew}$ point $\left({ }^{\circ} \mathrm{C}\right) ; 41.5=$ constant. 
Statistical analysis was performed by the method of least squares, as Harvey (1960), based on the following model:

$$
\mathrm{Y}_{\mathrm{ijklm}}=\mu+\mathrm{A}_{\mathrm{ji}}+\mathrm{H}_{\mathrm{k}}+\mathrm{E}_{\mathrm{l}}+\mathrm{IGTH}_{\mathrm{ijkl}}+\mathrm{RF}_{\mathrm{ijkl}}+\mathrm{SR}_{\mathrm{ijkl}}+\mathrm{HF}_{\mathrm{ijkl}}+\mathrm{e}_{\mathrm{ijklm}}
$$

Where $Y_{\mathrm{ijklm}}=\mathrm{mth}$ average; $\mu=$ is the overall mean; $A_{\mathrm{ji}}=$ random effect of the $\mathrm{jth}$ animal belonging to the ith period; $\mathrm{H}_{\mathrm{k}}=$ the fixed effect l-th collection time $(\mathrm{k}=1.4), \mathrm{IGTH}_{\mathrm{ijkl}}=$ index Globe Temperature and humidity of the 1-th collection, $\mathrm{j}$-th animal belonging to the $\mathrm{i}$-th species; $\mathrm{RF}_{\mathrm{ijkl}}=$ respiratory frequency 1 -th collection, $\mathrm{j}$-th animal belonging to the $\mathrm{i}$-th species; $\mathrm{SR}_{\mathrm{ijk} \mathrm{l}}=$ sweating rate of the l-th collection, $\mathrm{j}$-th animal belonging to the $\mathrm{i}$-th species; $\mathrm{RT}_{\mathrm{ijkl}}=$ rectal temperature of l-th collection, $\mathrm{j}$-th animal belonging to the $\mathrm{i}$-th species; $\mathrm{HF}_{\mathrm{ijk}}=$ heart frequency of 1-th collection, $j$-th animal belonging to the $i$-th species and $e_{i j k l m}=$ is the residue, including the random error.

The analysis of correlations and homogeneity of variance of the residual tests were performed using the SAS statistical program. To compare the results of the Tukey test $(\mathrm{P}<0.05)$ was applied, using the statistical package SAS version 9.1 (SAS, 2003).

\section{Results and Discussion}

This present study shows that there is influence of environmental variables with thermoregulatory characteristics of animals, because as increases or decreases the environmental variables provides variations in the frequencies of the mechanisms of thermal regulation in this animal. The mean air temperature (AT) set forth in Table 1, showed significant differences $(\mathrm{P}<0.05)$, showing a range of $10.48{ }^{\circ} \mathrm{C}$ between the period of lowest and higher temperature period. The results show the superiority of TA in the dry season, which presents higher incidence of solar rays mainly in the late shifts. Neiva et al. (2004) evaluated the effect of environmental stress on production and physiological parameters of Santa Inês sheep, observed that the elevation of temperature in the afternoon exerted influence on the rectal temperature and respiratory rate.

Observing Table 1, it was noticed that IGTH showed significant differences at $(\mathrm{P}<0.05)$ for both shift and for periods, concluding that there is the possibility that the animals leave the thermal neutral zone in the afternoon, regardless of are in the rainy season or dry season. Different values were obtained by Bezerra et al. (2011) in a study conducted in Soledad-PB with sheep (Dorper $1 / 2+1 / 21 / 2$ Damara SRD and SRD + 1/2) with 120 days of age, found values of 80.24 and 78.93 respectively for dry and rainy season. Cezar et al. (2004) Soledad-PB using 48 lambs (Santa Ines and crossbred Dorper) obtained similar values for the dry period, 75.5 and 82.4 corresponding to the morning and afternoon, it concluded that the experimental period the animals led to the situation of alert during the morning shift and the situation of thermal hazard during the afternoon shift, both considered as thermal discomfort to the animals. Silva et al. (2006) in a study in Cariri, registered in the shadow of IGTH 77.97 82.25 in the morning and afternoon.

Table 1. Averages of meteorological variables collected during shifts (morning and afternoon) in periods

\begin{tabular}{lccccc}
\hline \multirow{2}{*}{ Variables } & \multicolumn{2}{c}{ Dry Period } & & \multicolumn{2}{c}{ Rainy Period } \\
\cline { 2 - 3 } \cline { 5 - 6 } & In morning & In afternoon & & In morning & In afternoon \\
\hline $\mathrm{AT}\left({ }^{\circ} \mathrm{C}\right)$ & $23.01^{\mathrm{Ba}}$ & $31.78^{\mathrm{Aa}}$ & & $21.30^{\mathrm{Ab}}$ & $29.98^{\mathrm{Ab}}$ \\
$\mathrm{AH}(\mathrm{KPa})$ & $84.42^{\mathrm{Ab}}$ & $41.31^{\mathrm{Bb}}$ & & $94.25^{\mathrm{Aa}}$ & $53.93^{\mathrm{Ba}}$ \\
IGTH $\left({ }^{\circ} \mathrm{C}\right)$ & $75.95^{\mathrm{Ba}}$ & $81.51^{\mathrm{Aa}}$ & & $78.74^{\mathrm{Bb}}$ & $80.55^{\mathrm{Ab}}$ \\
\hline
\end{tabular}

Means followed by the same letter (capital) related to shifts and averages followed by the same letter (lowercase) for periods on the same line do not differ by Tukey test at $5 \%$ level of significance. $\mathrm{AT}=$ air temperature; $\mathrm{AH}=$ Air humidity; IGTH = Index Globe Temperature and Humidity.

The AH differed between sampling periods of this work, with superiority of the rainy season, it rains due to the presence of which provide the greatest amount of droplets of water vapor present in the air. In a study by Luz et al. (2012) analyzing the thermoregulatory parameters and environmental variables at different times of sheep with lambs Santa Inês and Morada Nova in Bom Jesus-PI, found values of 41.07 and 40.888 relating to the morning shift and late dry period and 96.50 and 72.60 for the morning and afternoon of the rainy season. Among the environmental factors, temperature and relative humidity have an important role to play, especially on animals entering edaphoclimatic in those regions of origin (Santos et al., 2002). Junior Barros et al. (2012) Assessing the influence of climate via thermoregulatory characteristics of dairy cows during the dry and rainy 
seasons of the year in Bom Jesus, Piauí, found values of 55.25 and 50.25 relating to shifts of the dry period and 93.80 and 67.30 relating to shifts of the rainy season .

The RF values presented in (Table 2) showed significant difference at $(\mathrm{P}>0.05)$ for the shifts and periods with an average high-stress. The respiration rate can quantify the severity of heat stress, in which a frequency of 40-60, 60-80, 80-120 strokes per minute featuring a low , medium-high , and high stress for ruminants, respectively, and up to 150 cattle and 200 sheep to the stress is classified as severe (Silanikove, 2000). Temperatures of up to $27.5{ }^{\circ} \mathrm{C}$ is presented within the thermal comfort zone for sheep according Bezerra et al. (2011). With this afternoon shifts are the biggest influencers in using this thermoregulatory mechanism. In a study with seven wool ewe lambs Santa Ines, lower values described by Eustáquio Filho et al. (2011).

Table 2. Ratings of thermal comfort index of Santa Inês sheep and Young Street during shifts (morning and afternoon) and periods (dry and wet) in Bom Jesus, PI

\begin{tabular}{|c|c|c|c|c|}
\hline \multirow{2}{*}{ Character } & \multicolumn{2}{|c|}{ Dry Period } & \multicolumn{2}{|c|}{ Rainy Period } \\
\hline & In morning & In afternoon & In morning & In afternoon \\
\hline RF (mov. per min.) & $62.65^{\mathrm{Ba}}$ & $67.87^{\mathrm{Aa}}$ & $54.50^{\mathrm{Bb}}$ & $65.10^{\mathrm{Ab}}$ \\
\hline $\mathrm{RT}\left({ }^{\circ} \mathrm{C}\right)$ & $38.50^{\mathrm{Ba}}$ & $38.96^{\mathrm{Aa}}$ & $38.45^{\mathrm{Ba}}$ & $39.05^{\mathrm{Aa}}$ \\
\hline $\mathrm{SR}(\mathrm{g} / \mathrm{m} / \mathrm{h})$ & $127.67^{\mathrm{Aa}}$ & $144.03^{\mathrm{Aa}}$ & $77.12^{\mathrm{Bb}}$ & $120^{\mathrm{Ab}}$ \\
\hline HF (beats per min.) & $88.29^{\mathrm{Ba}}$ & $94.45^{\mathrm{Aa}}$ & $71.71^{\mathrm{Bb}}$ & $80^{\mathrm{Ab}}$ \\
\hline
\end{tabular}

Means followed by the same letter (capital) related to shifts and averages followed by the same letter (lowercase) for periods on the same line do not differ by Tukey test at 5\% level of significance. RF $=$ Respiratory Frequency; $\mathrm{RT}=$ Rectal Temperature, $\mathrm{SR}=$ Sweating Rate, $\mathrm{HF}=$ Heart frequency.

Analyzing the values of RT is observed that due to low use of leverage by the body of animals, it showed no significant difference $(\mathrm{P}>0.05)$ between periods (Table 2), but was significant $(\mathrm{P}<0.05)$ between shifts, due to the higher temperature range have been observed between shifts and not between periods of the year, similar results were presented by Sousa Jr. et al. (2008) working with sheep, cattle and goats in semiarid region of the city of Sobral, north of the State of Ceará. The results of RT can be explained as a consequence of late shifts manifest lower humidity and high air temperature, thus bringing greater body heat in the afternoon. According Verissimo et al. (2009), who worked with Santa Inês sheep had an average rectal temperature of 38.4 and $38.7 \pm$ $0.09{ }^{\circ} \mathrm{C}$. According Cezar et al. (2004), with a job in the dry season found higher values of 39.50 and $40{ }^{\circ} \mathrm{C}$ for the morning and afternoon. Starling et al. (2002) study of Corriedale sheep in climatic chamber at $40{ }^{\circ} \mathrm{C}$, obtained average value of rectal temperature was $40.1 \pm 0.10^{\circ} \mathrm{C}$.

The SR was possibly not a major means of thermolysis used by animals in the shift between the dry period, but showed a difference $(\mathrm{P}<0.05)$ between shifts. Luz et al. (2012) found no difference between the dry and rainy for sheep Santa Ines and Morada Nova shifts. In a situation of thermal stress elevation of body temperature and, therefore, increased respiratory and skin evaporation and peripheral blood flow (Silanikove, 2000) occurs. The internal temperature of an animal is higher and decreases until its periphery (the skin), forming thermal gradient from the inner to the outer body (Baccari, 2001). According Santos et al. (2006), if the air temperature increases, heat loss decreases appreciably increasing the temperature of the core and thus the body of the animal by means of evaporative mechanisms, such as sweating and/or respiratory rate, increases heat dissipation insensitive.

The result of the HF showed significant differences $(\mathrm{P}<0.05)$ between shifts and periods studied in the present work, we note that the lower value of the dry period that was recorded in the morning (88.29) had a magnitude shift in relation to higher value of the dry period that was in the afternoon (80) shift, thus showing that the dry period possibly influenced in greater vasodilation in favor of homeothermy. Neiva et al. (2004) and Cezar et al. (2004) observed, in Santa Ines sheep kept the sun on the afternoon shift at room temperature of $33.2{ }^{\circ} \mathrm{C}$ and 32 values of 91 and 115.4 movements per minute.

The correlations between the thermoregulatory characteristics and environmental variables are presented in (Table 3$)$, where we noticed that the HF (-0.582) correlated negatively with the period, with the passage of dry to wet season provided a large reduction in HF, so as shown on Table 2. Animals use peripheral vasodilatation, or the increased blood flow to body surface as a process for maintaining homeothermy, caused an increase in the surface temperature of the animals, Ribeiro et al. (2008). This vasodilation facilitates the exchange of heat of the 
animal to the environment for sensitive processes and effectiveness of this mechanism depends on the temperature gradient between the body and the ambient temperature of the animal (McCutcheon \& Georg, 2008).

The RT (0.435) which correlated positively with AT, showing that there was influence of air temperature increased respiratory rate, as the temperature was higher in the late shifts and had a magnitude of the dry period possibly promoted the activation of this loss mechanism heat (Tables 1 and 2). According to Starling et al. (2002) in respiratory rate increased, so that increased dissipation of body heat by warming the inhaled air and evaporation airways. Luz et al. (2013) quantified correlations of 33.5\% indicating that there was a temperature difference inside the body of animals probably led to elevated respiratory rate.

Table 3. Correlation between thermoregulatory characteristics and meteorological variables sheep Santa Inês and Morada new in Bom Jesus, PI

\begin{tabular}{lcccccccc}
\hline Caract. & RF & AT & AH & SR & IGTH & HF & SHIFT & PER. \\
\hline RT & 0.092 & 0.419 & -0.455 & 0.004 & 0.423 & 0.295 & 0.461 & 0.016 \\
RF & & 0.435 & -0.385 & 0.014 & 0.072 & 0.348 & 0.385 & -0.247 \\
AT & & & -0.953 & 0.072 & 0.511 & 0.371 & 0.960 & -0.194 \\
AH & & & -0.034 & -0.519 & -0.372 & -0.908 & 0.273 \\
SR & & & & 0.132 & 0.107 & 0.069 & -0.195 \\
IGTH & & & & & 0.054 & 0.535 & 0.132 \\
HF & & & & & & & 0.271 & -0.582 \\
SHIFT & & & & & & & & 0.00
\end{tabular}

AT $=$ air temperature; $\mathrm{AH}=$ Air humidity; IGTH $=$ Index Globe Temperature and Humidity, RF $=$ Respiratory Frequency; RT = Rectal temperature, $\mathrm{SR}=$ Sweating Rate, $\mathrm{HF}=$ Heart Frequency, $\mathrm{PER}=$ period.

The RT (-0.455) correlated negatively with UA, but positively correlated with AT (0.419), as moisture reached a limit of influence on thermoregulatory feature turn the TA becomes the most influential environmental variable that characteristic, presented (Table 2) observed that late shifts were more stressful because the temperature was higher. The resistance of an animal to high temperatures is defined by the greater or lower ability to dissipate excessive body heat, thus managing to keep their average body temperature within the limits of homeothermy Medeiros et al. (2007). Rectal temperature is a good indicator of body temperature (Oliveira et al., 2005). According Cesar et al. (2004). The shift significantly influenced $(\mathrm{P}<0.05)$ rectal temperature, so that temperature was increased evening the morning.

The AT showed correlations of great magnitude with IGTH (0.511), the SHIFT (0.960) and AH (0.953), making intelligible that with the increase of air temperature directly influence these characteristics, as the humidity was high and negative correlation, evident that when the temperature was high moisture turn was low. The results were greatly influenced by the variation of AT, both promoting increased as providing the decrease of values. The high environmental temperature, humidity and direct sunlight are the main responsible for the discomfort that leads animals to adopt behavioral and physiological measures to maintain homeothermy, which implies the reduction of productive performance (Souza et al., 2010). When a sharp rise in air temperature occurs, the thermoregulatory mechanisms are activated, increasing heat loss in callously through sweating and increasing RF (Oliveira et al., 2005).

\section{Conclusion}

With the increase in air temperature and decrease in relative humidity during the dry period in the afternoon, took the animals to use in larger quantities physiological parameters to lose heat. However, it was found that in the late shifts of the two periods studied, the average sheep suffered heat stress. There was no loss of heat by sweating for periods, demonstrating that other mechanisms were sufficient for the sheep remain in homeothermy.

\section{Acknowledgements}

"The God who is the Lord of life and Our Lady for all the love and affection".

At the Federal University of Piauí (UFPI) and the Technical College of Bom Jesus (CTBJ), availability of 
animals and laboratories for research and Doctors and students who participated in this study.

\section{References}

Baccari, J. R. F. (2001). Manejo ambiental da vaca leiteira em climas quentes (p. 142). Londrina: Universidade Estadual de Londrina.

Barros Jr, C. P., Luz, C. S. M., Fonseca, W. J. L., Araujo, E. S., Sousa, G. G. T., \& Sousa Jr., S. C. (2012). Avaliação da influência do clima via características termorreguladoras de vacas leiteiras nos períodos seco e chuvoso do ano em Bom Jesus Piaui. Pubvet, 6(35), Ed. 222, Art. 1473.

Bezerra, W. M. A. X., Bonifacio, B. S., Sousa, W. H., Gomes, M. D. C., \& Alves, T. M. B. (2011). Comportamento fisiológico de diferentes grupos genéticos de ovinos criados no semiárido paraibano. Revista Caatinga, 24(1), 130-136.

Cezar, M. F., Souza, B. B., \& Souza, W. H. (2004). Avaliação de parâmetros físiológicos de Ovinos Dorper, Santa Inês e seus Mestiços perante condições climáticas do trópico semi-árido nordestino. Ciência e Agrotecnologia, 28(3), 614-620. http://dx.doi.org/10.1590/S1413-70542004000300018

Costa, R. G., Medeiros, A. N., Alves, A. R., \& Medeiros, G. R. (2009). Perspectivas de utilização da flor-de-seda (Calotropis procera) na produção animal. Revista Caatinga, 22(1), 1-9.

Eustáquio Filho, A., Teodoro, S. M., Chaves, M. C. A., Santos, P. E. F., Silva, M. W. R., Murta, R. M., ... Souza, L. E. B. (2011). Zona de conforto térmico de ovinos da raça Santa Inês com base nas respostas fisiológicas. Revista Brasileira de Zootecnia, 40(8), 1807-1814. http://dx.doi.org/10.1590/S1516-35982011000800026

Ferreira, R. A. (2005). Maior produção com melhor ambiente para aves, suínos e bovines (p. 371). Viçosa, MG: Aprenda Fácil.

Harvey, W. R. (1960). Least squares analysis of data with unequal suclass numbers. Beltsville, Md: ARS/USDA, Publicado.

Ibge-Instituto Brasileiro de Geografia e Estatística. (2010). Censo Agropecuário, Brasil.

Luz, C. S. M., Barros Junior, C. P., Fonseca, W. J. L., Pessoa Filho, J. A., Veiga, M. C. S., Sousa, G. G. T., ... Santos, K. R. (2012). Parâmetros termorreguladores e variáveis ambientais de ovinos em diferentes épocas do ano no sul do estado do Piaui. Pubvet, 6(35), Ed. 222, Art. 1474.

Luz, C. S. M., Barros Junior, C. P., Fonseca, W. J. L., Pessoa Filho, J. A., Veiga, M. C. S., Sousa, G. G. T., ... Santos, K. R. (2013). Estudo sobre correlações entre variáveis ambientais e mecanismos de termolise de calor de ovinos no Sul do Estado do Piaui. Pubvet, 7(7), Ed. 230, Art. 1525, Abril.

Mccutcheon, L. J., \& Geor, R. J. (2008). Thermoregulation and exercise-associated heat stress. In K. W. Hinchcliff, R. J. Geor, \& A. J. Kaneps (Eds.), Equine exercise physiology: The science of exercise in the athletic horse (pp. 382-386). Philadelphia: Elsevier. http://dx.doi.org/10.1016/B978-070202857-1.50018-4

Medeiros, L. F. D., Vierira, D. H., Oliveira, C. A., Fonseca, C. E. M., Pedrosa, I. A., Guerson, F. D., ... Madeiro, A. S. (2007). Avaliação de parâmetros fisiológicos de caprinos SPRD (sem padrão racial definido) pretos e brancos de diferentes idades, à sombra, no município do Rio de Janeiro. B. Indústria Anim., 64(4), 277-287.

Neiva, J. N. M., Teixeira, M., Turco, S. H. N., Oliveira, S. M. P., \& Moura, A. A. A. N. (2004). Efeito do estresse climático sobre os parâmetros produtivos e fisiológicos de ovinos Santas Inês mantidos em confinamento na região litorânea do Nordeste do Brasil. Revista Brasileira de Zootecnia, 33(3), 668-678. http://dx.doi.org/10.1590/S1516-35982004000300015

Oliveira, F. M. M., Dantas, R. T., Furtado, D. A., Nascimento, J. W. B., \& Medeiros, A. N. (2005). Parâmetros de conforto térmico e fisiológico de ovinos Santa Inês, sob diferentes sistemas de acondicionamento. Revista Brasileira de Engenharia Agrícola e Ambiental, 9(4), 631-635. http://dx.doi.org/10.1590/S1415-43662005000400029

Ribeiro, N. L., Furtado, D. A., Medeiros, A. N., Ribeiro, M. N., Silva, R. C. B., \& Souza, C. M. S. (2008). Avaliação dos índices de conforto térmico, parâmetros fisiológicos e gradiente térmico de ovinos nativos. Revista de Engenharia Agrícola, 28(4), 614-623. http://dx.doi.org/10.1590/S0100-69162008000400001

Santos, G. T., Cavalieri, F. L. B., \& Damasceno, J. C. (2002). Manejo da vaca leiteira no período transição e início de lactação. In G. T. Santos, A. F. Branco, \& U. Cecato (Eds.), Sustentabilidade da Pecuária Leiteira na Região Sul do Brasil (pp.143-165). Maringá: Gráfica Editora Sthampa.

Santos, J. R. S., Souza, B. B., Souza, W. H., Cezar, M. F., \& Tavares, G. P. (2006). Respostas fisiológicas e 
gradientes térmicos de ovinos das raças Santa Inês, Morada Nova e de seu cruzamentos cm a raça Dorper às condições do Semi-árido nordestino. Ciências Agrotécnicas, 30(5), 995-1001. http://dx.doi.org/10.1590/S1413-70542006000500025

Santos, R. (2003). A cabra e a ovelha no Brasil (p. 479). Uberaba: Agropecuária Tropical.

Sas Institute, SAS (Statistical Analysis System). (2003). User's Guide (p. 129). Cary, NC: SAS Institute Inc.

Schleger, A. V., \& Turner, H. G. (1965). Sweating rates of cattle in the field and their reaction to diurnal and seasonal changes. Australian Journal Agricultural Research, 16, 92-106. http://dx.doi.org/10.1071/AR9650092

Silanikove, N. (2000). Effects of heat stress on welfare of extensively managed domestic ruminants. Livestock Production Science, 67(S.1), 1-18. http://dx.doi.org/10.1016/S0301-6226(00)00162-7

Silva, E. M. N., Souza, B. B., Silva, G. A., Cezar, M. F., Souza, W. H., Benício, T. M. A., \& Freitas, M. M. S. (2006). Avaliação da Adaptabilidade de Caprinos Exóticos e Nativos no semiárido Paraibano. Revista Ciência e Agrotecnologia, 30(3), 516-521.

Silva, R. G. (2000). Introdução à Bioclimatologia Animal (p. 286). São Paulo: Nobel.

Sousa Jr, S. C., Morais, D. E. F., Vasconcelos, A. M., Nery, K. M., Morais, J. H. G., \& Guilhermino, M. M. (2008). Características Termorreguladoras de Caprinos, Ovinos e Bovinos em Diferentes Épocas do Ano em Regiao Semiárida. Revista Científica de Produção Animal, 10(2), 127-137.

Souza, B. B., Lopes, J. J., Roberto, J. V. B., Silva, M. A., Silva, E. M. N., \& Silva, G. A. (2010). Efeito do ambiente sobre os parâmetros fisiológicos de caprinos Saanen mestiços $1 / 2$ Saanen $+1 / 2$ Boer no Semi-Árido paraibano. Agropecuária Cientifica no Semi-Árido, 6, 47-51.

Starling, J. M. C., Silva, R. G., Cerón-Muñoz, M., Barbosa, G. S. S. C., \& Costa, M. J. R. P. (2002). Análise de algumas variáveis fisiológicas para avaliação do grau de adaptação de ovinos submetidos ao estresse por calor. Revista Brasileira de Zootecnia, http://dx.doi.org/10.1590/S1516-35982002000800022

Starling, J. M. C., Silva, R. G., Negrão, J. A., Maia, A. S. C., \& Bueno, A. R. (2005). Variação estacional dos hormônios tireoideanos e do cortisol em ovinos em ambiente tropical. Revista Brasileira de Zootecnia, 34(6), 2064-2073. http://dx.doi.org/10.1590/S1516-35982005000600032

Veríssimo, C. J., Titto, C. G., Katiki, L. M., Bueno, M. S., Cunha, E. A., Mourão, G. B., ... Titto, E. A. L. (2009). Tolerância ao calor em ovelhas Santa Inês de pelagem clara e escura. Revista Brasileira de Saúde Be Produção Animal, 10(1), 159-167.

\section{Copyrights}

Copyright for this article is retained by the author(s), with first publication rights granted to the journal.

This is an open-access article distributed under the terms and conditions of the Creative Commons Attribution license (http://creativecommons.org/licenses/by/3.0/). 